\title{
Leech therapy: a non-surgical management for varicose vein
}

\author{
Arshid Iqbal $^{1 *}$, Afroza Jan², Adil Rashid, Syed Anayat ${ }^{1}$
}

${ }^{1}$ Scientist, Regional Research Institute of Unani Medicine, Jammu and Kashmir, India

${ }^{2}$ Assistant Professor, Department of BBA, Gandhi Memorial College Srinagar, Jammu and Kashmir, India

Received: 03 December 2021

Revised: 28 January 2022

Accepted: 29 January 2022

\section{*Correspondence:}

Dr. Arshid Iqbal,

E-mail: drarsheediqbal@gmail.com

Copyright: () the author(s), publisher and licensee Medip Academy. This is an open-access article distributed under the terms of the Creative Commons Attribution Non-Commercial License, which permits unrestricted non-commercial use, distribution, and reproduction in any medium, provided the original work is properly cited.

\begin{abstract}
Varicosity refers to multiple, dilated, tortuous, and elongated veins that have permanently lost their valvular efficiency, such as haemorrhoids, varicocele, and esophageal varices. Varicose veins are twisted and enlarged veins that are commonly found in the legs. When veins become varicose, the valves stop working properly, allowing blood to flow backwards and the veins to engorge. Varicose veins are most common in the superficial veins of the legs, with the veins engorging and ulcerating as a result of standing under high pressure. The purpose of this case series is to evaluate the efficacy of Hirudotherapy in the treatment of varicose veins in the lower legs. Hirudotherapy was carried out scientifically by employing appropriate hygienic measures, and 8 to 10 leeches were used locally to suck the blood and transmit important bioactive enzymes that could aid in the treatment of varicose veins of the lower legs. Hirudotherapy was given every ten days for 60 days, and patients were monitored for a year. Leech therapy was found to significantly reduce venous engorgement by resolving edema, inflammation, and venous congestion.
\end{abstract}

Keywords: Leech, Vein, Hemorrhoids, Varicocele

\section{INTRODUCTION}

Varicose veins are named after the Latin word "varix," which means "dilated vein," and are most likely derived from the word "varus," which means "bent."1 Multiple, dilated, tortuous, and elongated veins that have permanently lost their valvular efficiency, such as haemorrhoids, varicocele, and esophageal varices, are referred to as varicosity. ${ }^{2}$ Bloodletting is based on the concept of Humoral imbalance, according to the Unani system of medicine. Their imbalance causes diseases, while restoring the balance results in health. According to the Unani System of Medicine, the majority of diseases are caused by endogenous factors such as an excess of morbid humours. ${ }^{1}$ Bloodletting, such as venesection, leech therapy, and cupping with scarification, is an important part of USM for surgical diseases. It has been used for thousands of years by ancient Unani physicians as a preventive and therapeutic measure. ${ }^{3}$ In developed countries, the reason for choosing treatment for varicose veins is cosmetic, whereas complications are the reason in developing countries such as India. ${ }^{4}$ Hobbs demonstrated that varicose veins in the legs could be caused by ovarian vein reflux, and Lumley and his colleagues demonstrated that recurrent varicose veins could be caused by ovarian vein reflux. ${ }^{5,6}$ Whiteley and his colleagues discovered that ovarian and internal iliac vein reflux both cause leg varicose veins, and that this condition affects $14 \%$ of women with varicose veins and $20 \%$ of women who have had vaginal delivery and have leg varicose veins. ${ }^{7}$ There is mounting evidence that incompetent perforator veins (or "perforators") play a role in the formation of varicose veins and recurrent varicose veins. ${ }^{8,9}$ Hyperhomocysteinemia in the body can also degrade and inhibit the formation of the three main structural components of the artery: collagen, elastin, and proteoglycans. ${ }^{10}$ 


\section{CASE SERIES}

The present study is single group open case clinical study. Twenty patients were selected from general outpatient department (OPD) who qualified the inclusion criteria and were screened before undergoing the scientific study. Our aim was to evaluate the safety and efficacy of a hirudotherapy in the management of varicose veins. In addition to this our objective is to provide the safe, patient friendly and toxicity free alternative therapy for the patients of varicose veins. The present study has been carried out at Regional Research Institute of Unani Medicine. Hirudotherapy was done scientifically by taking appropriate hygienic measures and about 10-15 leeches were used locally to suck the blood and transmit the important bioactive enzymes which could help in the treatment of varicose veins of lower legs. Hirudotherapy was done after every ten days for a period of 60 day and the patients were followed up for a period of one year. Patients with unilateral and bilateral varicose veins of lower limbs aging in between 25 to 65 years with either sex Patients. However, patients with varicose veins as well as peripheral vascular disease (PVD), patients having thrombophlebitis, patients already having deep vein thrombosis (DVT), patients with bleeding disorder, lower limb varicose veins with pregnancy or per abdominal masses are excluded. The diagnosis of varicose vein has been done clinically and following techniques of test has been carried out through trendelenberg test, perthes test and doppler auscultation. The recorded data was compiled and entered in a spreadsheet (Microsoft Excel) and then exported to data editor of SPSS Version 20.0 (SPSS Inc., Chicago, Illinois, USA). Statistical software SPSS (version 20.0) and Microsoft Excel were used to carry out the statistical analysis of data. Continuous data was expressed as Mean \pm SD and categorical data was expressed in terms of frequency and percentages. Paired t-test was employed for before -after comparison of limb girth. A Pvalue of less than 0.05 was considered statistically significant.

\section{Results}

In this section we will presents results in tabular and graphical form.

We observe that majority of patients are from 45-55 year age group.

Most of the patients had damvi mizaj (40\%) status followed by balghami (30\%) and safravi mizaj (20\%).

It is clear that most of the patients are agricultural workers constituting about $55 \%$.

The maximum percentage of patients have a history upto 8 years.

On the application of McNemar test, we observe that both SFJ and SPJ significantly improved after the treatment.
We observe that severity of pigmentation colour and area resolved significantly after the treatment.

Table 1: Age distribution of patients.

\begin{tabular}{|lll|}
\hline Age group & $\begin{array}{l}\text { Number of } \\
\text { patients }\end{array}$ & Percentage \\
\hline $\mathbf{2 5 - 3 5}$ & 2 & 10 \\
\hline $\mathbf{3 5 - 4 5}$ & 5 & 25 \\
\hline $\mathbf{4 5 - 5 5}$ & 12 & 60 \\
\hline $\mathbf{5 5 - 6 5}$ & 1 & 5 \\
\hline Total & 20 & 100 \\
\hline
\end{tabular}

Table 2: Occupational status of patients.

\begin{tabular}{|lll|}
\hline Occupation & $\begin{array}{l}\text { Number of } \\
\text { patients }\end{array}$ & Percentage \\
\hline $\begin{array}{l}\text { Agriculture } \\
\text { Workers }\end{array}$ & 09 & 45 \\
\hline Traffic Police & 02 & 10 \\
\hline Vendors & 09 & 45 \\
\hline Total & 20 & 100 \\
\hline
\end{tabular}

Table 3: Distribution of patients according to history.

\begin{tabular}{|lll|}
\hline History & $\begin{array}{l}\text { Number of } \\
\text { patients }\end{array}$ & Percentage \\
\hline Family & 04 & 20 \\
\hline Up to 3 year & 04 & 20 \\
\hline Up to 8 year & 07 & 35 \\
\hline $\begin{array}{l}\text { More than 8 } \\
\text { year }\end{array}$ & 05 & 25 \\
\hline Total & 20 & 100 \\
\hline
\end{tabular}

Table 4: Number of incompetent valves before vs after.

\begin{tabular}{|lclc|}
\hline Parameter & BT & AT & P-value \\
\cline { 1 - 3 } SFJ & 11 & 3 & \multirow{2}{*}{$<0.0001 *$} \\
\hline SPJ & 14 & 4 & \\
\hline \multicolumn{2}{l}{ McNemar test applied } & & \\
\hline
\end{tabular}

Table 5: Effect of leech application on pigmentation colour and area in varicose vein patients (Median with range).

\begin{tabular}{|c|c|c|c|}
\hline Parameter & BT & AT & P-value \\
\hline $\begin{array}{l}\text { Pigmentaion } \\
\text { colour }\end{array}$ & $3(0,3)$ & $1(0,2)$ & $<0.0001 *$ \\
\hline $\begin{array}{l}\text { Pigmentation } \\
\text { area }\end{array}$ & $\begin{array}{l}210(53, \\
867)\end{array}$ & $\begin{array}{l}88(3, \\
150)\end{array}$ & $<0.0001 *$ \\
\hline
\end{tabular}

From the above results we observe that there is a significant decrease in limb girth after the treatment $(\mathrm{p}<0.0001 *)$ which infers that the treatment is effective in decreasing the limb girth. 
Table 6: Comparison of limb girth at site of varicosity in lower limb before and after the treatment.

\begin{tabular}{|llllll|l|}
\hline & & & & \\
& $\begin{array}{l}\text { Comparisol } \\
\text { of limb girtl }\end{array}$ & Mean & N & $\begin{array}{l}\text { Std. } \\
\text { deviati } \\
\text { on }\end{array}$ & $\begin{array}{l}\text { SE } \\
\text { Mean }\end{array}$ & $\begin{array}{l}\text { P } \\
\text { value }\end{array}$ \\
\hline Limb & BT & 38.92 & 2 & 1.5481 & 0.346 & \\
girth & 50 & 0 & 3 & 17 & $<0.000$ \\
(cm) & AT & 37.54 & 2 & 1.5428 & 0.344 & \multirow{2}{*}{$*$} \\
& 00 & 0 & 6 & 99 & \\
\hline
\end{tabular}

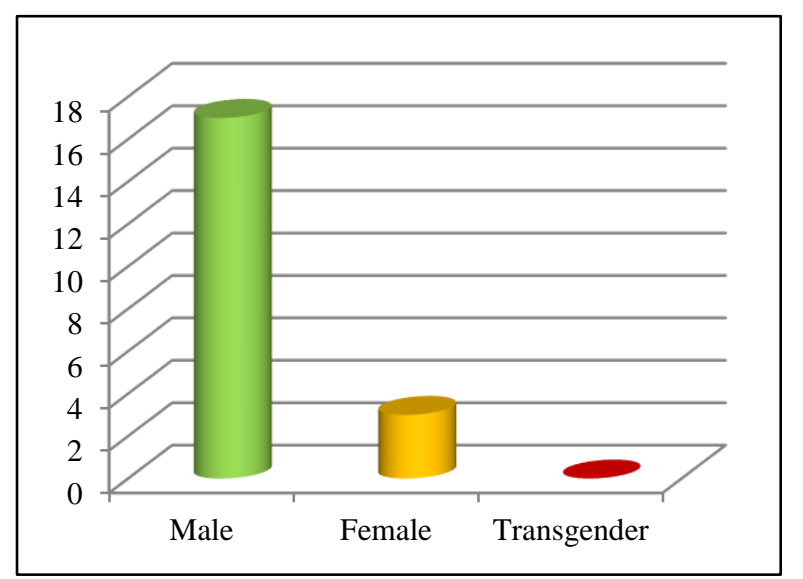

Figure 1: Number of patients according to sex.

\section{DISCUSSION}

Varicose veins can cause a number of symptoms in the legs, but they must be distinguished from the many other causes of leg pain. The Edinburgh vein study discovered that itching, heaviness, and aching were significantly related to varicose veins, but the relationship between these symptoms and varicose veins was inconsistent, especially in men. Varicose veins can be aggravated by superficial thrombophlebitis ("phlebitis"). Deep vein thrombosis is rare, but it has occurred in a case series on rare occasions when phlebitis extends above the knee. Veins can become permanently occluded in some cases. In the current study, we discovered that males outnumber females, which is consistent with the findings of Nigar et al. ${ }^{15}$ In contrast, several authors have reported female predominance over males. ${ }^{16,17}$ In the current study, we discovered that the majority of patients are between the ages of 45 and 55, with damvi mizaj (40\%) being the most common, followed by balghami $(30 \%)$ and safravi mizaj $(10 \%)$. (20\%). Contrary to the findings of numerous authors the majority of the patients (55 percent) were agricultural workers. ${ }^{15,18,19}$ Varicose veins complications include bleeding, skin changes, and ulcers, all of which necessitate treatment. They are all linked to high venous pressure in the upright position, which is caused by incompetent venous valves. Bleeding is uncommon and usually occurs from a prominent vein on the leg or foot that is covered by thin, dark, unhealthy skin. "Skin changes" range from eczema to brown discoloration to florid lipodermatosclerosis with subcutaneous tissue indurations.
Many people have telangiectases on their legs, which are also known as thread, spider, or broken veins. Small dark blue reticular veins are common as well. All of these are purely cosmetic in nature. They are not the same as varicose veins, though they frequently occur together. Many people with varicose veins are concerned about deep vein thrombosis, but the varicose veins of the legs are distinct from the deep veins. During people's normal daily lives, varicose veins pose no proven risk of deep vein thrombosis. Varicose veins caused by a deep vein thrombosis are uncommon. However, varicose veins and deep vein incompetence can coexist, especially in people with complications such as lipodermatosclerosis or ulcers, making treatment more difficult. The current study found that hirudotherapy effectively reduces limb girth, improves blood thinning, and lymph flow in varicose veins. The improvement can be attributed to the accelerated effect of leech sclerotherapy as well as the presence of natural steroid in leech saliva. Hirudotherapy appears to be effective in reducing limb girth, according to the findings. Nigar et al found similar results. ${ }^{15}$ Varicose veins reduce blood supply to the heart due to incompetent valves, resulting in blood stasis, which contributes to edoema. ${ }^{20}$ Due to incompetent valves, varicose veins reduce blood supply to the heart, resulting in blood stasis, which contributes to edoema. ${ }^{21-23}$

\section{CONCLUSION}

Hirudotherapy significantly improves varicose vein symptoms. This is due to leech sclerotherapy's potent antiinflammatory, blood thinning, and lymph flow accelerating effects, as well as the presence of natural steroid in leech saliva, which aids in the treatment of varicose veins. Based on the findings, we can conclude that Hirudotherapy had no side effects and was effective in treating symptoms such as colour change, vein engorgement, edoema, itching, heaviness, and limb pain. Hirudotherapy was also thought to improve venous valvular function by alleviating SFJ incompetence with reflux on valsulva and SPJ incompetence in cases of small saphenous vein involvement.

\section{ACKNOWLEDGEMENTS}

Authors duly acknowledge the Assistant Director Incharge and Hospital, library staff of Regional Research Institute of Unani Medicine, Srinagar, J\&K, India.

Funding: No funding sources Conflict of interest: None declared Ethical approval: Not required

\section{REFERENCES}

1. Tibbs DJ. Varicose veins and related disorders. Butterworth-Heinemann.First edition. 1992;25-6.

2. Pavan Prasad BK, Prem Kumar A. Clinical Study of varicose veins and their management. International Journal Biomed Advance Res. 2015;6(08):564-8. 
3. Itrat M, Zarnigar, Haque N. Historical Aspect of Leech Therapy: A Critical Review. International Journal of Health Science and Research. 2013;3(7):78-83.

4. $\mathrm{Ng} \mathrm{M}$, Andrew T, Spector T, Jeffery S. Linkage to the FOXC2 region of chromosome 16 for varicose veins in otherwise healthy, unselected sibling pairs." Journal of Medical Genetics. 2005;42(3):235-9.

5. Hobbs JT. Varicose veins arising from the pelvis due to ovarian vein incompetence. Int $\mathrm{J}$ Clin Pract. Int $\mathrm{J}$ Clin Pract. 2005;59:1195-203.

6. Giannoukas AD, Dacie JE, Lumley JS. Recurrent varicose veins of both lower limbs due to bilateral ovarian vein incompetence". Ann Vasc Surg. 2000; 14:397-400

7. Marsh P, Holdstock J, Harrison C, Smith C, Price BA, Whiteley MS. Pelvic vein reflux in female patients with varicose veins: comparison of incidence between a specialist private vein clinic and the vascular department of a National Health Service District General Hospital". Phlebology. 2009;24:108-13.

8. Whiteley MS. Part One: For the Motion. Venous Perforator Surgery is Proven and Does Reduce Recurrences. European Journal of Vascular and Endovascular Surgery. 2014;48(3):239-42.

9. Rutherford EE, Kianifard B, Cook SJ, Holdstock JM, Whiteley MS. Incompetent perforating veins are associated with recurrent varicose veins. European Journal of Vascular and Endovascular Surgery. 2001;21(5):458-60.

10. Shenoy KR. Varicose veins and deep vein thrombosis. Manipal manual of surgery 2009, Millennium edition. 87-9.

11. Phipps, Sands, Marek. Medical surgical nursing 6th ed. Philadelphia: Mosby Publication. 1999.

12. Health J. varicose veins and spider veins. Available at: http;//body and fitness.com/information/womenhealth/varicose.htm. Accessed on 20 November 2021.

13. Campbel B. Varicose veins and their management. BMJ. 2006;333(7562):287-92.

14. Curri SB. Changes of cutaneous microcirculation from elasto-compression in chronic venous insufficiency. In Davy A and Stemmer R (eds.) Phlebology '89, Montrouge, France, 'John Libbey Eurotext. 1989.

15. Nigar Z, Alam MA. Effect of taleeq (leech therapy) in dawali (varicose veins). Ancient science of life. 2011;30(3):84-91.

16. Anonymous. The McMillan Family Encyclopaedia. London: fraction, decreasing reflex \& reducing the residual volume McMillan Press Ltd. 1995;271.

17. Verma PS. A manual of practical zoology invertebrates. New 33 emptying of the valvular cusps. Improve the muscle Delhi: S Chand \& Company Ltd. 2006;288-91.

18. Laurikka J, Sisto T, Auvinen O, Tarkka M, Hakama M. Varicose veins in a Finnish population aged. 2020;40-60.

19. Canonico S, Gallo C, Paolisso G, Pacifico F, Signoriello G. venous insufficiency with various kinds of compression \& Sciaudone G, Ferrara N, Piegari V, Varricchio, Rengo F. Prevalence of varicose veins in an Italian elderly population. measurements \& various methods of plethysmography. Angiology. 1998;49:129135.12.

20. Evans CJ, Fowkes FGR, Ruckley CV, Lee AJ. Prevalence ofaN, Hannerz H, Burr H, Kristensen TS. Standing at work and varicose veins. Scand J Work Environ Health. 2000;26:414420.

21. Jawien A, Grzela T, Ochwat A. Prevalence of chronic venous insufficiency (CVI) in men and women in Poland: Multicentre cross-sectional study in 40,095 patients Phlebology 2003; 18: 110122

22. Tuchsen F, Krause N, Hannerz H, Burr H, Kristensen TS Standing at work and varicose veins. Scand J Work Environ Health. 2000;26:414420.

23. Mechallsen A, Roth M, Dobos G. Medical Leech Therapy.. Publication Thieme, New York, USA. 2007;11-12:132-8.

Cite this article as: Iqbal A, Jan A, Rashid A, Anayat S. Leech therapy: a non-surgical management for varicose vein. Int J Reprod Contracept Obstet Gynecol 2022;11:904-7. 